\title{
Applying a 3D Body Scanner to Qualify the Postures and Direction of Changes in Human Body by Children Example
}

\author{
Wioletta SYBILSKA, Elżbieta MIELICKA* \\ Textile Research Institute, Lodz, Poland
}

\begin{abstract}
The aim of this study was to determine the direction and extent of changes in the body structure and dimensions of selected boys and girls age groups. Anthropometric measurements of about 50 girls and 40 boys at the age of $10-12$ attending primary schools in Lodz were performed. The measurements were carried out using an Anthroscan 3D VITUS Smart XXL scanner, which is in the possession of the Textile Research Institute. Within this study the average values of body size were determined for each group of the persons tested. A comparison of selected anthropometric characteristics of girls and boys with the results obtained in previous years was made. Based on the figure images and longitudinal sections, the assessment of figures was made by means of a visual method, comparing the profiles of girls sectional views obtained from the scanner with the standard of Staffel's typology. The comparative analysis of test results derived from 2010 confirmed the thesis concerning the increase of children body size in relation to anthropometric dimensions made in 1998.
\end{abstract}

Keywords: $3 d$ body scanning, posture of body, children, anthropometric measurements

\section{Introduction}

In many countries detailed examinations have been carried out to update information on the body structure and proportions of the inhabitants of a given country. The most recent anthropometric measurements performed in Germany have shown that the citizens of that country are increasingly taller and stronger. The examinations were carried out by four teams using a $3 \mathrm{D}$ scanner (a contactless method) within the period from 1th July 2007 to 31th October 2008 in 31 towns. 13362 men, women and children at the age of 6 to 87 were examined. The test results showed that in the case of women at the age from 14 to 70 , their height was increased on the average by $1 \mathrm{~cm}$, chest circumference was $+2.3 \mathrm{~cm}$, waist circumference: $+4.1 \mathrm{~cm}$ and hip circumference: $+1.8 \mathrm{~cm}$ compared to the results of 1994 [1].

It is commonly observed that younger and younger teenager groups attain the body height of adults. At the same time, this phenomenon is accompanied by the growth acceleration of particular body sections (e.g. length and width of feet, length and circumferences of shank and thigh) [2]. Moreover, the average value of relative body mass index (BMI) has increased, which indicates increasing obesity problem in the Polish population. This is accompanied by changes in the fatty tissue distribution resulting in fat accumulation on abdomen and in hip regions. From generation to generation, one can observe a growing fraction of persons of extremely low and extremely high body weight [3].

Nowadays it is the faulty posture that constitutes a crucial health problem. Violent changes in the man's life environment adversely affect his existence. A human being, in his/her defensive-adaptive mechanisms, is unable to keep pace with the dynamics of civilization changes, as shown by the mass-observed disturbances of posture. Two critical periods occur within the school years. The first one is connected with the change in life mode and the start of learning at school at the age of $6-7$. The beginning of learning at school usually brings about posture deterioration with a simultaneous need of motion. The second critical period occurs at the age of $11-14$ for girls and $12-16$ for boys. This is a period of maturation connected with intensive changes in body proportions and the position of gravity center and a rapid body height growth with no compensation by the power of muscles. The body posture is eventually formed at the end of youthful period at the age of $15-18$ for girls and 17 20 for boys [4].

The result of deviations from the proper posture is an improper body posture or body shape (in a free standing position) resulting from the structure and habitual or compulsory location of particular body parts, disadvantageous to the organism.

Faulty postures often include improper head position, shoulder asymmetry or faulty positioned and winged scapulae. Such deviations are classified as posture faults. The faulty postures of most frequent occurrence include: rounded back, concave back, concave-rounded back, flat back, lateral curvature of the spine (scoliosis), static faults of lower limbs.

Winged scapulae, shoulders asymmetry and ribs and chest asymmetry are classified as faulty postures [4]. 


\section{Methods}

Examinations were performed with the use of a system for contactless measurements of human body: Anthroscan 3D VITUS Smart XXL from Human Solutions (Fig. 1). This system is equipped with 4 scanners placed in corners of a room and a computer system, whose software allows one to record over 100 measurements of human silhouette and to analyze the data obtained. The software is capable of automatic scanning in various (standing or sitting) positions according to the following standards [5, 6]:

PN-EN-13402-2:2004 Determination of garment size. Part 2: basic and additional measurements; ISO 8559:1989 Garment construction and anthropometric surveys;

PN- EN ISO 7250:2005 Basic measurements of human body for technical designing.

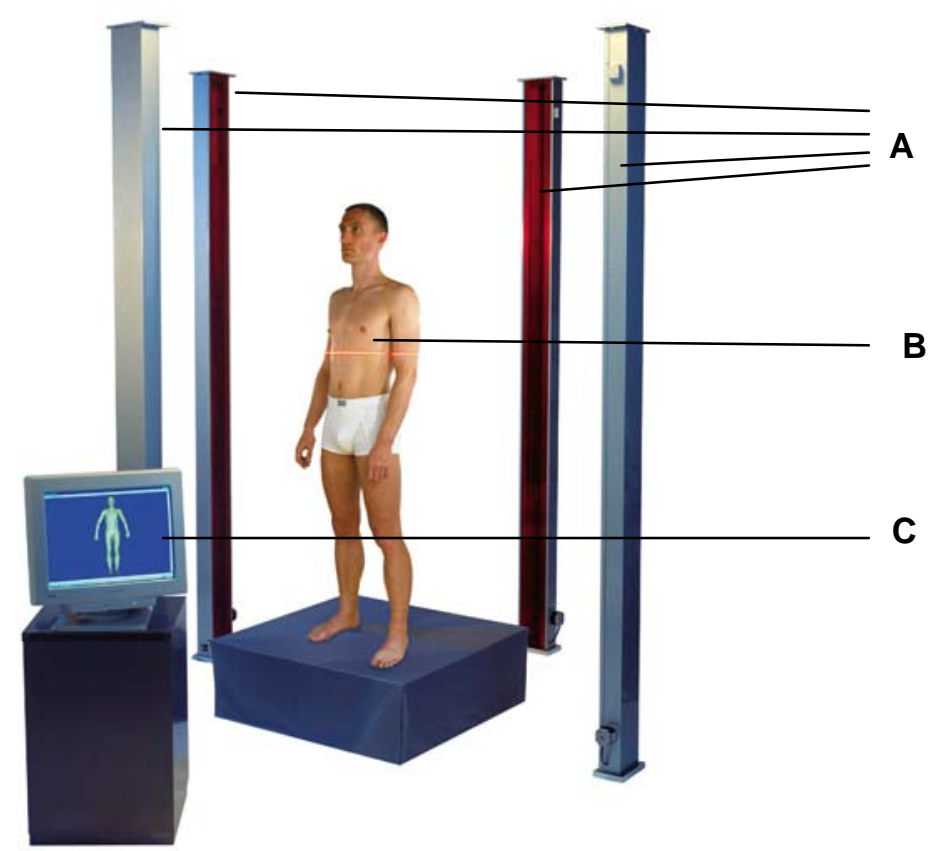

Fig. 1. Stand for contactless measurements: $A$ - 4 scanners, $B$ - object under measurements, $C$ - computer system for recording measurement data [5]

Anthropometric measurements were carried out for about 50 girls and about 40 boys at the age of 10 12 , going to Elementary Schools in Łódź. Selected anthropometric features of the children tested were compared with the results obtained for that age group in previous years.

Based on the shape images obtained and the longitudinal cross-sections, the assessment of silhouettes was made comparing the views of silhouette cross-sections obtained from the scanner with Staffel's posture standard according to five types of posture:

1. Norma posture

2. Rounded back

3. Flat back

4. Concave back

5. Rounded-concave back

\section{Results}

Considering the extent of assessment and a great number of measurements, only selected, most important and corresponding to our assumptions results are presented in this paper. For each measurement, silhouette cross-sections were made at the level of waist and belly and their circumferences were calculated by means of the software used. The results obtained are shown in Figure 2 nearby silhouettes. 


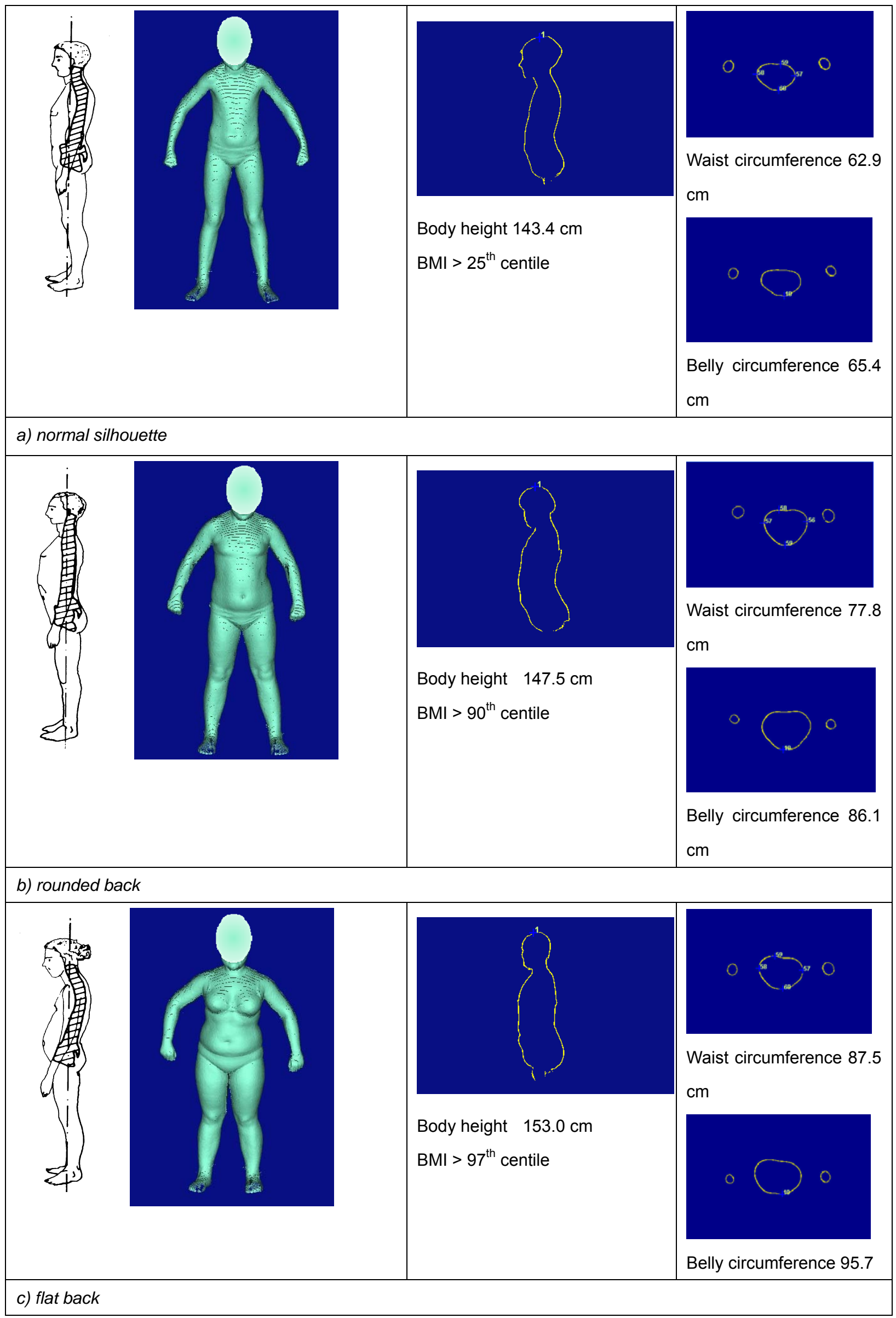




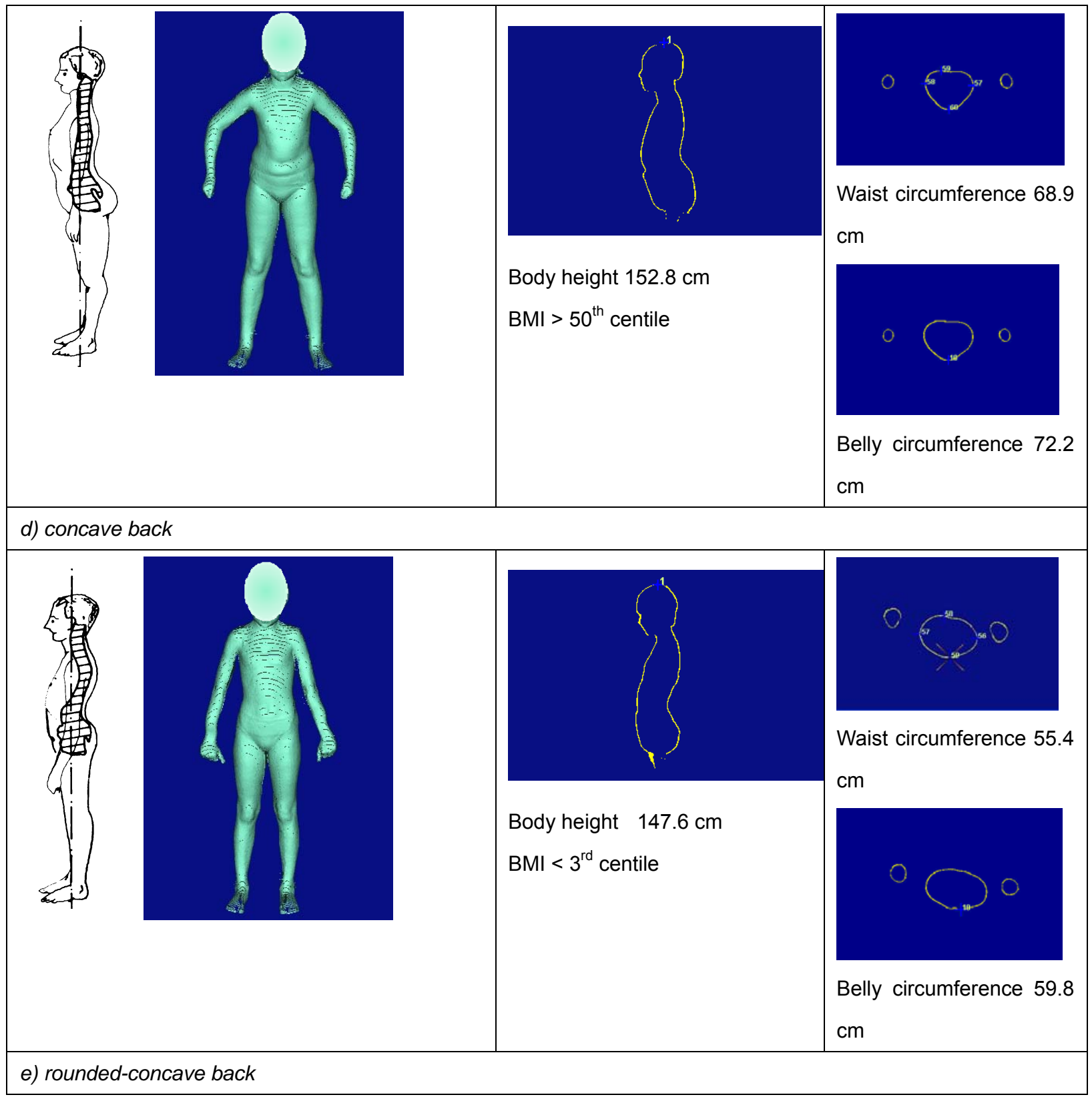

Fig. 2.Silhouette images and views of cross-sections obtained with the use of the scanner

The measurements of body mass and height were used to calculate the body mass index (BMI) according to the following formula [7]:

$$
B M I=\frac{(\text { body mass })[\mathrm{kg}]}{(\text { body height })^{2}\left[\mathrm{~m}^{2}\right]}
$$


The body mass index (BMI) of 25 and $30 \mathrm{~kg} / \mathrm{m}^{2}$ constitutes a criterion for the diagnosis of the adult overweight and obesity but in the population of developmental age, one should carefully use this index. In the case of children and teenagers, one cannot use these recommendations since the value of BMI depends on sex and changes with age. The assessment of the extent of body mass deficiency or excess in the population of developmental age is made by means of centile networks or BMI tables for sex and age [8].

The BMI values obtained were compared with the tables of values read from the centile networks for an appropriate age interval (Table 1).

Table 1.Centile values of BMI of girls according to age [9]

\begin{tabular}{|c|c|c|c|c|c|c|c|c|c|c|c|}
\hline \multirow{3}{*}{$\begin{array}{l}\text { Age } \\
\text { (years) }\end{array}$} & \multicolumn{11}{|l|}{ Girls } \\
\hline & \multicolumn{11}{|c|}{ Centiles } \\
\hline & 3 & 5 & 10 & 15 & 25 & 50 & 75 & 85 & 90 & 95 & 97 \\
\hline 10 & 13,5 & 13,9 & 14,1 & 14,7 & 15,2 & 16,6 & 18,5 & 19,9 & 20,7 & 22,8 & 24,0 \\
\hline 11 & 13,7 & 14,1 & 14,6 & 15,2 & 15,8 & 17,3 & 19,3 & 20,7 & 21,5 & 23,5 & 24,5 \\
\hline 12 & 14,2 & 14,7 & 15,1 & 15,7 & 16,4 & 18,0 & 19,9 & 21,5 & 22,4 & 24,1 & 24,9 \\
\hline
\end{tabular}

When the BMI value of the person tested is in the centile network below the 5th centile, we are dealing with the deficiency of body mass (Fig. 2e). The BMI value corresponding to a value between $85^{\text {th }}$ and $95^{\text {th }}$ centile is classified as body overweight (Fig. 2b). Obesity is recognized when the BMI value corresponds to a value equal or higher than $95^{\text {th }}$ centile (Fig. 2C). .

The material collected was processed by means of basic statistical characteristics such as arithmetic mean and standard deviation that were used to assess the level of selected anthropometric features of girls and boys in the age groups tested. For independent tests, the statistical significance of differences between test results of 2010 and 1998 was determined by means of Student's t-test. Statistical significance was analyzed at the level $p \leq 0.05$.

The average values of girl and boy body heights and waist circumferences are listed in Tables 2 and 3 , Tables 4 and 5 show the differences between the arithmetic means derived from 2010, 1998, 1988 and 1978.

Table 2.Comparison of girl body dimensions in 1978, 1988, 1998 and 2010 (arithmetic means, standard deviation)

\begin{tabular}{|c|c|c|c|c|c|c|c|c|}
\hline \multirow[t]{2}{*}{ Age } & \multicolumn{4}{|c|}{ Body height, cm } & \multicolumn{4}{|c|}{ Waist circumference, $\mathrm{cm}$} \\
\hline & 1978 & 1988 & 1998 & 2010 & 1978 & 1988 & 1998 & 2010 \\
\hline 10 & $136,5(6,2)$ & $138,0(6,6)$ & $139,3(6,2)$ & $144,6(6,1)$ & $57,8(5,3)$ & $58,1(5,7)$ & $60,8(6,6)$ & $62,1(5,5)$ \\
\hline 11 & $142,4(7,1)$ & $144,4(7,5)$ & $145,0(7,8)$ & $151,9(7,2)$ & $59,7(5,5)$ & $59,8(6,0)$ & $60,9(6,0)$ & $68,5(9,5)$ \\
\hline 12 & $149,2(7,3)$ & $150,3(7,7)$ & $150,2(7,4)$ & $159,5(5,3)$ & $62,0(6,1)$ & $61,9(6,2)$ & $63,0(6,4)$ & $70,7(8,5)$ \\
\hline
\end{tabular}

Table 3.Comparison of boy body dimensions in 1978, 1988, 1998and 2010 (arithmetic means, standard deviation)

\begin{tabular}{|c|c|c|c|c|c|c|c|c|}
\hline \multirow[t]{2}{*}{ Age } & \multicolumn{4}{|c|}{ Body height, cm } & \multicolumn{4}{|c|}{ Waist circumference, $\mathrm{cm}$} \\
\hline & 1978 & 1988 & 1998 & 2010 & 1978 & 1988 & 1998 & 2010 \\
\hline 10 & $136,9(5,7)$ & $138,4(6,3)$ & $140,5(5,6)$ & $141,6(6,6)$ & $59,5(5,3)$ & $59,8(5,8)$ & $62,8(7,6)$ & $67,3(9,4)$ \\
\hline 11 & $141,8(6,1)$ & $142,8(6,6)$ & $144,5(6,9)$ & $151,4(5,3)$ & $61,1(5,7)$ & $61,0(6,1)$ & $64,6(7,8)$ & $72,2(10,5)$ \\
\hline 12 & $146,9(7,1)$ & $148,6(7,2)$ & $150,5(7,7)$ & $155,9(6,1)$ & $63,0(6,0)$ & $62,9(6,7)$ & $67,5(9,6)$ & $72,2(11,3)$ \\
\hline
\end{tabular}


Table 4.Differences in girl and boy body heights

\begin{tabular}{|c|c|c|c|c|c|}
\hline \multirow{2}{*}{$\begin{array}{l}\text { Age, } \\
\text { years }\end{array}$} & \multicolumn{5}{|c|}{ Body height, cm } \\
\hline & $\begin{array}{l}\text { Difference } \\
2010-1998\end{array}$ & $\begin{array}{l}\text { Difference } \\
1998-1988\end{array}$ & $\begin{array}{l}\text { Difference } \\
1988-1978\end{array}$ & $\begin{array}{l}\text { Average } \\
\text { trend } \\
2010-1998\end{array}$ & $\begin{array}{l}\text { Average } \\
\text { trend per } \\
\text { decade } \\
(2010-1998)\end{array}$ \\
\hline \multicolumn{6}{|l|}{ Girls } \\
\hline 10 & 5,3 & 1,3 & 1,5 & 0,44 & 4,4 \\
\hline 11 & 6,9 & 0,6 & 2,0 & 0,58 & 5,8 \\
\hline 12 & 9,3 & $-0,1$ & 1,1 & 0,78 & 7,8 \\
\hline \multicolumn{6}{|l|}{ Boys } \\
\hline 10 & 1,1 & 2,1 & 1,5 & 0,09 & 0,9 \\
\hline 11 & 6,9 & 1,7 & 1,0 & 0,58 & 5,8 \\
\hline 12 & 5,4 & 1,9 & 1,7 & 0,45 & 4,5 \\
\hline
\end{tabular}

Table 5.Differences in girl and boy waist circumferences

\begin{tabular}{|c|c|c|c|c|c|}
\hline \multirow{2}{*}{$\begin{array}{l}\text { Age, } \\
\text { years }\end{array}$} & \multicolumn{5}{|c|}{ Waist circumference, $\mathrm{cm}$} \\
\hline & $\begin{array}{l}\text { Difference } \\
2010-1998\end{array}$ & $\begin{array}{l}\text { Difference } \\
1998-1988\end{array}$ & $\begin{array}{l}\text { Difference } \\
1988-1978\end{array}$ & $\begin{array}{l}\text { Average } \\
\text { trend } \\
2010-1998\end{array}$ & $\begin{array}{l}\text { Average } \\
\text { trend per } \\
\text { decade } \\
(2010-1998)\end{array}$ \\
\hline \multicolumn{6}{|l|}{ Girls } \\
\hline 10 & 1,3 & 2,7 & 0,3 & 0,11 & 1,1 \\
\hline 11 & 7,6 & 1,1 & 0,1 & 0,63 & 6,3 \\
\hline 12 & 7,7 & 1,1 & $-0,1$ & 0,64 & 6,4 \\
\hline \multicolumn{6}{|l|}{ Boys } \\
\hline 10 & 4,5 & 3,0 & 0,3 & 0,38 & 3,8 \\
\hline 11 & 7,6 & 3,6 & $-0,1$ & 0,63 & 6,3 \\
\hline 12 & 4,7 & 4,6 & $-0,1$ & 0,39 & 3,9 \\
\hline
\end{tabular}

From the data presented in Tables 4 and 5 it follows that within 32 years positive differences appeared in the majority of the features tested. Only a decrease or a slight increase in waist circumference was observed in 1998. Besides this exception, the materials collected confirm typical change tendencies. From the data listed in Table 2 and 4 it follows that the average body height of the pupils tested has increased within 32 years. It is clearly seen among 12 years old girls: their average body height has increased by $10.5 \mathrm{~cm}$, which means $3 \mathrm{~cm}$ per a decade. Surely, the positive action of environmental factor has contributed to some extent to the positive trend of the basic somatic feature, such as body height, in 1978-2010. As follows from the above fact, the direction of differences is consistent with literature data $[2,3,7,8]$.

The values of the anthropometric features of girls and boys at the age of $10-12$ were compared with corresponding data of 1998. The test results for girls are shown in Fig. 3 and those for boys in Fig. 4. 


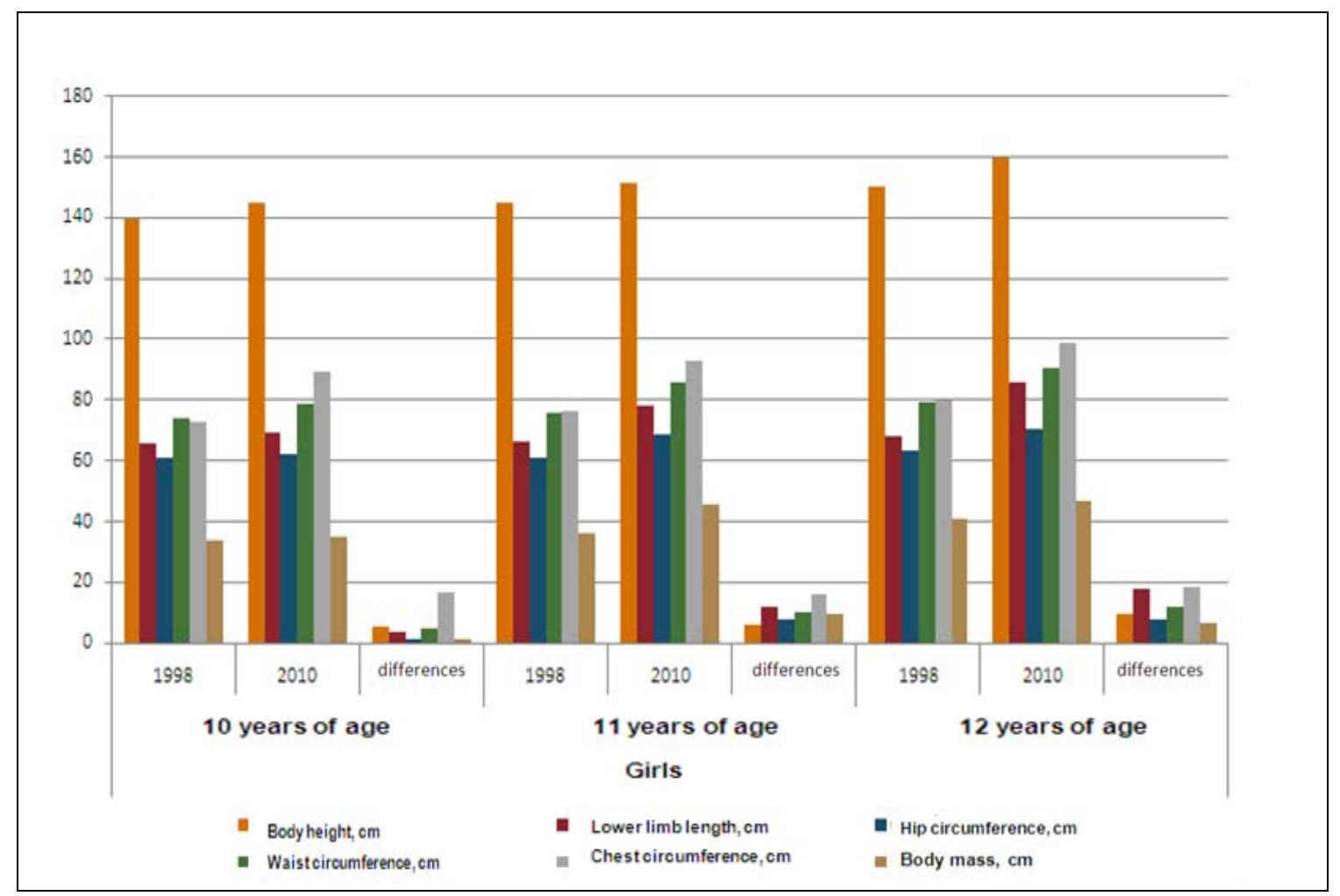

Fig. 3. Average values of the girls anthropometric measurements

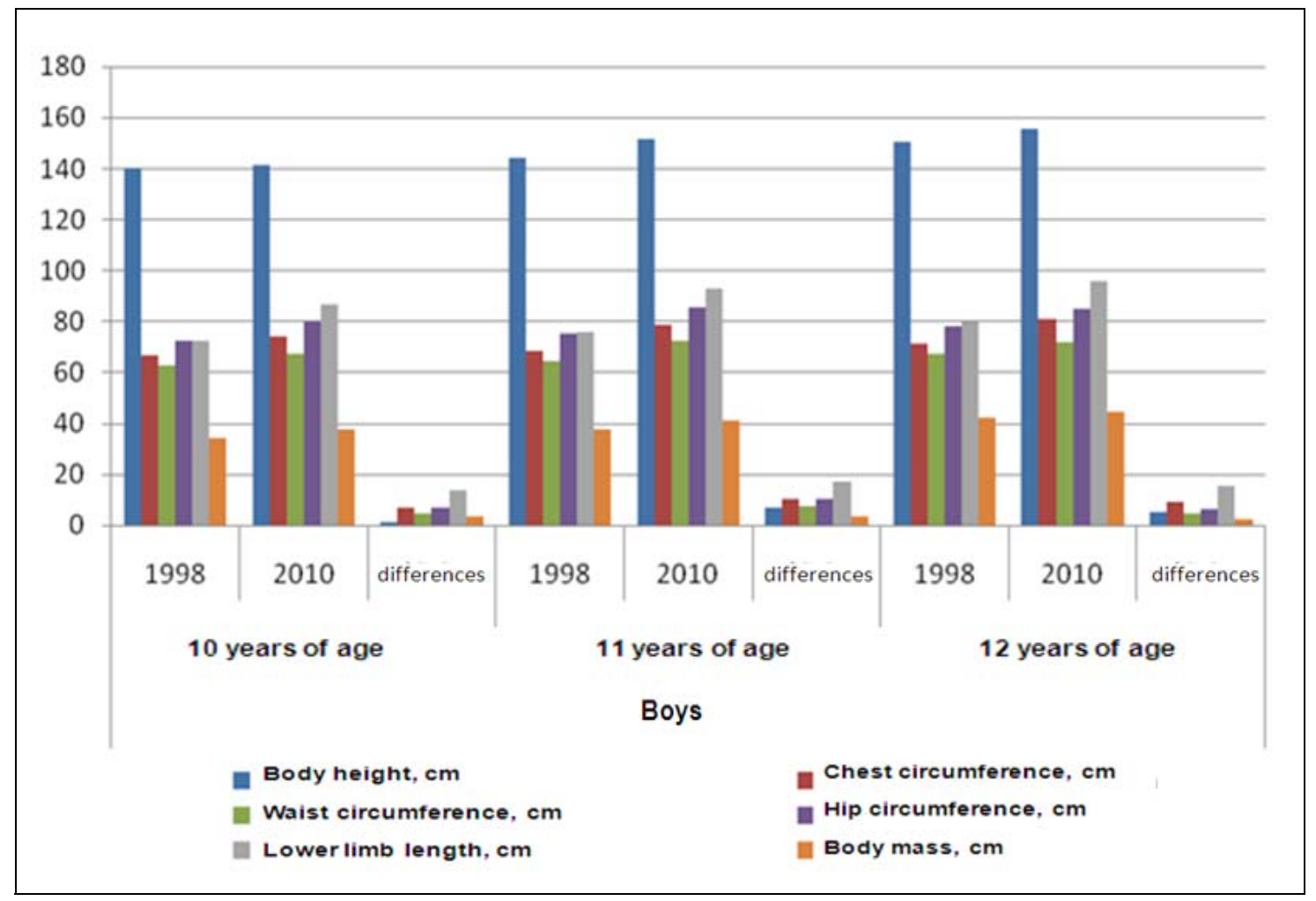

Fig. 4. Average values of boys anthropometric measurements 
The comparative analysis of test results from 2010 (Figs 3 and 4) confirms the thesis concerning the increase in children body dimensions in relation to the anthropometric measurements made in 1998. Body height has been increased in each age interval. The highest increments in circumferences took place in the case of girls at the age of 12 (Fig. 3); this especially concerns waist and hips circumferences. The hips circumference of girls at the age of 12 has been considerably increased.

The body circumferences of boys have been also increased showing considerable increments in waist and hips circumferences. Analyzing the data shown in Fig 4, one can observe that the highest increase in waist circumference occurred in the case of boys at the age of 11 . The changes in the body structure of girls and boys result mainly from their getting fat; this especially concerns girls.

The significance of differences in average values was determined by means of t-test and the results obtained are listed in Table 6.

Table 6. Results of variable value $t$

\begin{tabular}{|l||l|l|l|l|l|l||}
\hline \multirow{2}{*}{ Feature tested } & \multicolumn{2}{|l}{ Girls } & \multicolumn{2}{l|}{ Boys } \\
\cline { 2 - 8 } & $\begin{array}{l}10 \text { years } \\
\text { of age }\end{array}$ & $\begin{array}{l}11 \text { years } \\
\text { of age }\end{array}$ & $\begin{array}{l}12 \text { years } \\
\text { of age }\end{array}$ & $\begin{array}{l}10 \text { years } \\
\text { of age }\end{array}$ & $\begin{array}{l}11 \text { years } \\
\text { of age }\end{array}$ & $\begin{array}{l}12 \text { years } \\
\text { of age }\end{array}$ \\
\hline Body height, cm & 2.75 & 2.92 & 4.60 & 0.64 & 3.41 & 2.28 \\
\hline Chest circumference, cm & 2.03 & 7.21 & 10.37 & 3.19 & 5.23 & 3.99 \\
\hline Waist circumference, cm & 0.63 & 4.36 & 4.04 & 1.78 & 3.21 & 1.55 \\
\hline Hips circumference, cm & 2.22 & 5.37 & 5.62 & 3.11 & 4.69 & 2.51 \\
\hline Lower limbs length, cm & 10.81 & 12.66 & 14.06 & 10.40 & 13.22 & 10.13 \\
\hline $\begin{array}{l}\text { Boundary value } \mathrm{t}_{0,95} \text { read } \\
\text { from tables }\end{array}$ & 1.96 & 1.96 & 1.96 & 1.96 & 1.96 & 1.96 \\
\hline
\end{tabular}

Using the Anthroscan system for contactless measurement of human body, one can rapidly and directly obtain over 100 anthropometric measurements to examine and assess body posture and determine the body mass index (BMI). This 3D scanning method provides a complete image of human silhouette allowing precise anthropometric measurements and the results obtained are saved in a data base thus there is no need to repeat the examination.

The test results presented in this paper concerning children at the age of $10 \div 12$ lat were compared with the test results derived from 1998. The statistical significance (at the significance level $\alpha=0,05$ ) of difference between the girl and boy body measurements originating from 1998 and those obtained in 2010 was examine. Student's t-test has shown that there can be a statistically significant difference between the average values of body height, chest circumference, hips circumference, lower extremities length and waist circumference (in the case of boys and girls at the age of 11). On the other hand, there are no statistically significant differences between the average values of waist of boys at the age of 10 and 12 and 10 years old girls as well as between the average values of body height of boys at the age of 10 . It may be assumed that this phenomenon results from the improvement in life conditions of the persons tested and different susceptibilities of boys and girls to specified life conditions, in which the Polish society live. 


\section{References}

1. Informacje, Przegląd WOS 3/2010.

2. Bielicki T., Welon Z., Waliszko A., (1981): „Zmiany w rozwoju fizycznym młodzieży w Polsce w okresie 1955-1978", Monografie ZA PAN, Wrocław.

3. Welon Z., Szklarska A., (2000): „Prognoza wysokości ciała mężczyzn w Polsce na lata 2000-2020”, Wychowanie Fizyczne i Sport, 2/2000.

4. Karbowniczek K., Wołowska I., ,Wady postawy u dzieci w młodszym wieku szkolnym - profilaktyka i korekcja", http://ares.21sp.lublin.pl/3/inne/wady postawy.htm

5. http://dl-designline.de/mode-nach-mass-massgescheidert/bodyscanner.htm, www.human-solution.com, www.vitus.de

6. Sybilska W., Napieralska L., Mielicka E.; (2010): "Analysis Of Body Measurements Using A 3d Contactless Scanning Method", Autex Research Journal, No 3 Vol. 10. Str. 77-79.

7. Dziecko Łódzkie, Metody badań i normy rozwoju biologicznego, pod redakcją A. Malinowskiego i D. Chlebnej - Sokół, (1998) Łódź.

8. Konstantynowicz J., Piotrowska-Jastrzębska J., Kaczmarski M., Kłopotowski M., Motkowski R., Abramowicz P., (2003): „Densytometryczna i antropometryczna ocena tkanki tłuszczowej u młodzieży w wieku 13-19 lat", Endokrynologia Pediatryczna, Tom. 2, Nr 1(2), s. 21-31.

9. Jodkowska M., Wojnarowska B., Oblacińska A., (2007): „Test przesiewowy do wykrywania zaburzeń w rozwoju fizycznym u dzieci i młodzieży w wieku szkolnym", Materiały metodyczne dla pielęgniarek szkolnych oraz lekarzy podstawowej opieki zdrowotnej, Warszawa. 